University of Nebraska - Lincoln

DigitalCommons@University of Nebraska - Lincoln

Publications from USDA-ARS / UNL Faculty

U.S. Department of Agriculture: Agricultural

Research Service, Lincoln, Nebraska

2011

Emerging Challenges in Soil Management

Jerry L. Hatfield

USDA-ARS, jerry.hatfield@ars.usda.gov

Thomas J. Sauer

USDA-ARS, tom.sauer@ars.usda.gov

Follow this and additional works at: https://digitalcommons.unl.edu/usdaarsfacpub

Hatfield, Jerry L. and Sauer, Thomas J., "Emerging Challenges in Soil Management" (2011). Publications from USDA-ARS / UNL Faculty. 1375.

https://digitalcommons.unl.edu/usdaarsfacpub/1375

This Article is brought to you for free and open access by the U.S. Department of Agriculture: Agricultural Research Service, Lincoln, Nebraska at DigitalCommons@University of Nebraska - Lincoln. It has been accepted for inclusion in Publications from USDA-ARS / UNL Faculty by an authorized administrator of DigitalCommons@University of Nebraska - Lincoln. 


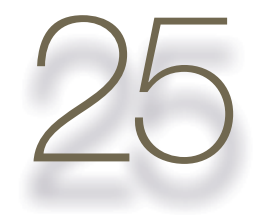

\title{
Emerging Challenges in Soil Management
}

\author{
Jerry L. Hatfield and Thomas J. Sauer
}

Soil provides a number of important functions, including agronomic and biomass productivity, purifying water, biodegradation of pollutants, regulating greenhouse gases (GHGs) emission from the soil surface, and providing a foundation for civil and urban structures. This is a wide range of functions, but the most critical function for humanity is providing the fundamental resource for the production of the food, feed, fiber, and fuel required to sustain the ever-increasing human population. In the history of agriculture, there has never been a time in which the importance of proper management of the soil resource has been more critical. Jenny (1980) pointed out that the functions of soil represent the diverse capabilities of soil and the multiple purposes of soil in answering a variety of human needs, from food to shelter.

The increase of the world's population from 6 to 9 billion over the next 30 to 40 years requires that the soil resource be carefully managed to increase the world's food supply. This has to be done in the face of an ever-degrading soil resource and an increasing variation in climatic resources and uncertainty in precipitation. The management of the soil resource to achieve this level of production will require that we better understand how soil responds to various practices. Within this volume we have assembled information to help establish a knowledge base to guide how we can cope with these challenges in providing a secure food supply in the face of a changing climate.

There have been continual assessments in the past few years that indicate soil condition continues to decline in terms of the organic matter content, soil structure, and potential rooting depth. Lal (1993) used the following expression to provide a framework for the assessment of soil quality, $S_{\mathrm{q}^{\prime}}$ by combining the following attributes, $S_{\mathrm{q}}=f(P, S, R, e, N, B)_{t^{\prime}}$ where $P$ is productivity, $S$ is an index of structural properties, $R$ is rooting depth, $e$ is charge density, $N$ is nutrient reserve, $B$ is a measure of biological diversity, and $t$ is time. If we dissect this relationship, it is evident that soil quality is a function of a number of different parameters, ranging from the basic soil structure to the productivity of the agricultural system in terms of both yield and adding organic material back to the soil. This framework provides a ready reference as to the role of soil management practices in influencing the components affecting soil quality. An important aspect of Lal's approach is the incorporation of the nutrient component in the soil. Management of nutrients to achieve optimal productivity of different agricultural systems is part of the foundation of improving our capabilities of producing the food needed

J.L. Hatfield, Laboratory Director and Plant Physiologist, National Laboratory for Agriculture and the Environment, 2110 University Blvd., Ames, IA 50011 (jerry.hatfield@ars.usda.gov); T.J. Sauer, USDA-ARS, National Laboratory for Agriculture and the Environment, 2110 University Boulevard, Ames, IA 50011-3120 (Tom.Sauer@ars.usda.gov).

doi:10.2136/2011.soilmanagement.c25

Copyright $\odot$ 2011. American Society of Agronomy and Soil Science Society of America, 5585 Guilford Road, Madison, WI 53711, USA. Soil Management: Building a Stable Base for Agriculture. Jerry L. Hatfield and Thomas J. Sauer (ed.) 
to supply the increasing population. In this book we have provided an exploration of the current state of knowledge on critical nutrients and the emerging challenges in nutrient management.

One of the major challenges will be how to balance the need for the increased production of food, feed, fuel, and fiber with the need for enhanced environmental quality. Water and air quality continue to be major problems linked with soil management. One of the functions of soil is the purification of water, but there is increasing concern regarding the linkage between agricultural practices and movement of nitrate nitrogen and phosphorus into nearby water bodies. Manure is a valuable source of nutrients for agricultural systems and offers the potential to enhance the soil from a physical, chemical, and biological perspective. Improved manure management systems coupled with practices to decrease tillage represent an area in which soil management will have to be refined and the knowledge base expanded. In spite of the offsite movement of nutrients and agricultural chemicals, the loss of sediment from fields should still be of concern to everyone because of its long-term impacts on the soil resource. Water and wind erosion processes need to be understood for soils around the world to reduce the impact of these two major forces on the soil and also to identify management practices that could be implemented to reduce these erosion losses. A fundamental change in philosophy away from "tolerable" soil loss towards soil improvement is desperately needed if future generations are to have access to land resources to meet their needs. The continued loss of soil by erosion and tillage is increasing the spatial variation across agricultural landscapes and threatens to impact the potential for efficient production. Soil management practices that either lessen the impact of this spatial variation or enhance the soil in areas degraded by erosion or tillage will provide a lasting benefit to the soil and ultimately to humanity. However, the effectiveness of these practices needs to be evaluated and based on sound scientific principles so that the information will be transferable among regions. In this volume, our goal was to provide both an understanding of the basis for soil management practices and to provide an overview of different practices that could be adapted.

There are rapidly changing practices in terms of cropping systems being proposed. The development of biofuels based on either corn stover removal or planting of lands to perennial grasses for harvest of cellulosic materials for ethanol production or direct biomass burning creates a potential new stress on the soil in terms of water use, nutrient management, and protection of the soil resource. These are not easy questions to address because the problem changes in scope from being only a single field problem to a regional landscape problem encompassing a range of soils, topographies, and microclimates. Sound soil management practices that can be implemented as part of these production systems will have to account for how these systems utilize soil water, extract nutrients, and change the overall biology of the soil system. The challenge will be not only to increase production but also to increase the diversity of production that can be used for a variety of purposes.

Transitioning from oil to biofuels as part of the renewable fuel standard brings into discussion the role of soil and agricultural systems as part of the global carbon balance. The global carbon balance is part of the overall effort to understand the role of agricultural practices in both the mitigation and sequestration processes for GHGs. Carbon storage in soil has been considered a positive for the GHG uptake and enhances soil quality because of the role that increased carbon has on the organic matter content of the soil and the resultant improvement in soil water-holding capacity, soil biological processes, and nutrient cycling. These processes extend beyond carbon and include methane and nitrous oxide as critical GHGs. Improving our understanding of the role soil management plays in altering the GHG exchange will help drive whole new approaches in GHG mitigation strategies. One aspect of cropping systems that offers potential for improving the carbon capture is through the use of cover crops. Effective management and adaptation of cover crop systems across a wider range of soils and cropping systems will offer the potential of multiple benefits for carbon, water, and nutrient management with the challenge 
to develop and implement cover crop systems that are cost-effective and enhance the environment.

The role soil has on supplying adequate and timely nutrients, water, and oxygen to plants is critical to the development of cropping systems that operate at the highest level of efficiency. To meet the production needs for the next 50 years will require that we focus our energies on improved soil management practices leading to increased efficiency of water and nutrient use. The next revolution in agriculture won't be a result of any single factor but rather resilient production systems capable of coping with any number of stresses. Too often we focus on soil management impacts on the cropping systems and fail to address the critical aspects of pest management. The indirect impacts of pests on production systems are often overlooked and deserve greater attention as we move forward in understanding the role soil management has on production systems. Weeds, insects, and diseases are critical components in agricultural systems and are deserving of greater attention in future evaluations of soil management practices.

In assembling this volume, we selected chapter authors who would challenge our current thinking and provide insights into future efforts to enhance soil management practices. There are many gaps in our current knowledge, and we need to focus our efforts and discussion on how we can expand our knowledge base to fill those gaps, but also to provide educational tools to help scientists, consultants, and students understand the potential in improving soil management practices that enhance the soil, increase production efficiency, improve environmental quality, lessen pest pressure, and increase the capability of ensuring a stable and abundant supply of food, feed, fuel, and fiber for future generations. If we are indeed in the midst of a soil science renaissance (Hartemink and McBratney, 2008), there could be no better outcome than dramatic, new, and innovative improvements in soil management practices that protect and sustain this critical resource for future generations

\section{References}

Hartemink, A.E, and A. McBratney. 2008. A soil science renaissance. Geoderma 148:123-129.

Jenny, H. 1980. The soil resources. Springer-Verlag, New York.

Lal, R. 1993. Tillage effects on soil degradation, soil resilience, soil quality and sustainability. Soil Tillage Res. 27:1-8. 
